Portland State University

PDXScholar

1971

\title{
An exploratory study of children's mental health needs in the PACT target area of southeast Portland
}

\author{
Richard L. Bossardt \\ Portland State University \\ Clifford G. Larsen \\ Portland State University
}

Follow this and additional works at: https://pdxscholar.library.pdx.edu/open_access_etds

Part of the Clinical and Medical Social Work Commons, Maternal and Child Health Commons, and the Mental Disorders Commons

Let us know how access to this document benefits you.

\section{Recommended Citation}

Bossardt, Richard L. and Larsen, Clifford G., "An exploratory study of children's mental health needs in the PACT target area of southeast Portland" (1971). Dissertations and Theses. Paper 1454.

https://doi.org/10.15760/etd.1453

This Thesis is brought to you for free and open access. It has been accepted for inclusion in Dissertations and Theses by an authorized administrator of PDXScholar. Please contact us if we can make this document more accessible: pdxscholar@pdx.edu. 
(AN EXXPLORATORY STUNY OF CHILDREN'S

MENTAL GEALTH NEEDS IN THE PACT TARGET AREA

OF SOUTHEAST PORTLAND)

by

Richard L. Bossardt

Clifford G. Larsen

Report of a Practicum Submitted to the Faculty of the School of Social. Work, Portland State University, in Partial Fulfiliment of the Requirements for the Degree of Master of Social Work

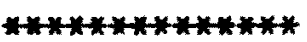

Portland State Untversity

May 15, 1971 
This practicum report has been reviewed and accepted.

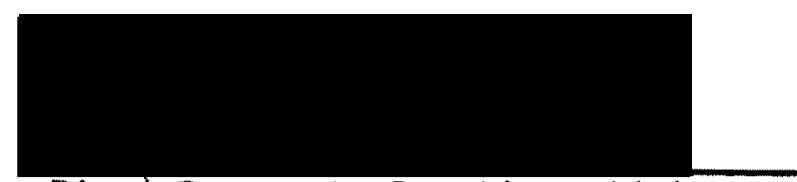

Diane Pancoast, Practicum Advisor Mpril of 19:1 Date

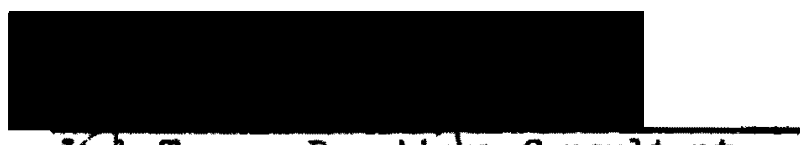

Jagk Tovey, Practidum Consultant Dateril 28,1911

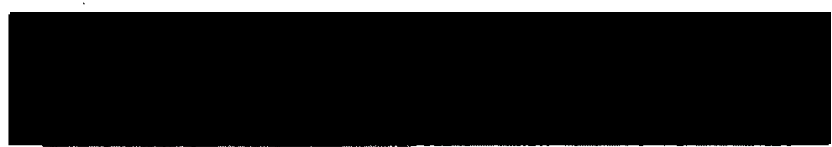

Deah Clarkson, Practicum Consultant April $30,1 \% 7$ Date 
P R E F A E

The original, and still primary, purpose of this study was to provide a statistical data base for a grant proposal to fund a children's mental health service agency in the PACT target area of Southeast Portland. Since the orfiginal conception by Jack Tovey of the Child Psychiatry Department, Univergity of Oregon Medical School, and PACT staff, the plan has been subsumed under the planning auspices of the Comprehensive Mental Health Planning Comittee, a group whose aim is to work toward expanding and consolidating mental health services in all dimensions for the Southeast Portland area.

PACT itself has expressed interest in using the practicum report for a variety of purposes:

A. Adding to the PACT file of community information and otatiatics for future reference.

B. Providing supporting data for a grant appeal to Portland UGN, the purpose of which would be to expand mental health services in the PACT target area.

C. As substantiating statistical data for a Child Adrocacy Program which would be adminiatered by PACT. Additionally, it is expected that the results of the practicum will be presented to the principals of the schools cooperating in the study, and it has been suggested that a presentation to the Portland Public School Board might also be in order. 
TABLE OF CONTENTS

Page

LIST Of 'TABlES. .......................... ii

INTRODUCTION. .......................... 1

METHODOLOGY AND ANALYSIS OF DATA. . . . . . . . . . . 7

SUMMARY AND CONCLUSTONS . . . . . . . . . . . . 23

APPENDIX A

Maps. ...................... 26

APPENDIX B

Statistics on Some PACT Area Social Problems. . . . . . 27

APPENDIX C

PACT Area School Statistics . . . . . . . . . 28 APPENDIX D

The Guided Interview Format. . . . . . . . . . . 29 
LIST OF TABLES

Page

I Responses to Question Two and Three..........

II Analysis of Responses to Question Two. .........

III Analysis of Responses to Question Three. . . . . . 


\section{INTRODUCTION}

The geographical focus of this study is on that section of Southeast Portland which has been designated by the Office of Economic Opportunity as a poverty pocket because of an incidence of low-income families exceeding 22\%. (See Figure 2, Appendix A.) As such, the area is under the jurisdiction of the Portland Metropolitan Steering Camittee, the OEO community action agency for Portland. Under the auspices of this agency, the four neighborhooda in the area (Brooklyn, Buckman, Richmond and Sunnyside) in 1966 formed a separate non-profit delegate agency which was named portland Action Committees Together, Incorporated (PACT). PACT originally was responstble for administering War on Poverty programs through three neighborhood centers in the area. Its functions have changed but it atill remains very much involved, even providing the terms by which the area is known: the PACr target area.

The particular focus of the study has to do with the mental health of elementary school aged children in the PACT target area. Three major inPluences converged in the choice of this focus: first, the authors are, by inclination and training, psychiatrically oriented; second, we became directly involved with disturbed children in a school setting as part of our second-year field placement in the area; third, we came in contact with Jack Tovey, social worker at the University of Oregon Medical School. Mr. Tovey and Dr. Carl Morrison of the Child Guidance Center, under the auspices of PACT, operationalized the Children's Mental Health Clinic at the outset of the 1970-71 school year. A sort of roving, comminity-based service agency using the PACT neighborhood canters and schoolo as temporary homes, the clinic 
began seeing referred elementary school aged children and their families on a one-balf day a week basis in an attempt to meet in some measure, what was felt to be a great need for children's mental health services in the area. The authors, in our school setting, simultaneously began engaging some of the children who were evaluated at the clinic in therapeutic relationships as follow-up, and our connection with the clinic's operation was formed. When we learned that Mr. Tovey and PACT staff were planning to write a grant proposal in order to fund a full-scale operation, we saw the possibility of performing a hopefully valuable service while at the same time, fulfilling the research requirercent for graduation.

In discussion with Mr. Tovey, it was learned that the actual need for such a service had never been researched in a formal way, although all of us, as a result of our experiences, felt that the need was not only existent, but considerable. It was decided that we would focus for the practicum on this problem, working with Mr. Tovey in the planning stages and making our data avallable to him in formulating hls grant proposal.

In the following pages, we wlll present a brlef description of the PACT target area which, it is hoped, will convey some feeling for the area and for the quality of life within it. Part of the observations are drawn from our experience of living in the area and working with some of 1ts people, but we are indebted for the bulk of the descriptive material to Rick Paulson, author of a compilation of atatistics on the area. ${ }^{1}$ We have paraphrased him freely and occasionally, quoted him outright. IPaulson, Rick, The Southeast Portland P.A.C.T. Target Area: A Commuity
Profile, W.I.C.H.E. Internahip Program, Ausust, 1970. 
The PACT area is home for approximately 40,650 people. It is the core area of Southeast Portland, and is characterized superficially by a wide range of land uses, ranging from heavy industrial and comercial activity along its western edge, to relatively quiet residential neighborhoods along the eastem edge. It is bisected at average intervals of every five blocks by east-west arterial streets which bear all of the traffic from the downtown business district and the eastern part of the oity. At less frequent intervals, north-south arterials pass through the area, cutting the east-west residential strips into long islands bounded on all sides by fast, heavy, noisy, and dirty traffic. Associated with these arterials are commercial otrips composed largely of filling stations, taverns, eating establiabments, an occasional supermarket or discount atore, particularly at the intersections of arterials, and small shops located In buildings dating back to trolley car days. Goods and services are widely dispersed, and the obsolete facilities are facing an ever increasing competitive gap with shopping centers and other more modern facilities. A significant number of ohop spaces are already vacant--mute testimony to changing commeralal needs.

Perhaps the most blighted section in the area is that located along its western edge, which is bounded by the Willamette River. As was mentioned previously, this section is primarily given over to heavy industrial and comercial activity, but a wide variety of land uses can be seen there, fram railroads to residences. The streets are narrow, the traffic is congested, there is very little vacant land and no room for industrial expansion except eastward into the residential areas. The effects of this situation on the 
adjacent residential areas are often disastrous: land values are high, residential structures are allowed to deteriorate by absentee landlords, and the population is shifting and unstable.

Indeed, an unstable population is one of the most outstanding characteristics of the PACT area. Aside from the rather less-than-positive Iiving conditions already touched on, perhaps one of the major reasons for the transiency of the area's people, has to do with housing. 1960 census date indicates that "more than $22 \%$ of all housing units in the area were deteriorating or dilapidated compared with a city rate of only $14 \%^{\prime 2}$ Paulson also cites two more recent surveys which indicate that the rate of substandard housing is much greater," even approaching $60 \%$ in some sections. 3 Many of these substandard units are associated with older, oingle-family dwellings which have been vacated by their owners and converted into apartments. In fact, much of the area is zoned for apartment buildings rather than for single-family dwellings, and it is becoming common practice to replace older homes with low-rise, short-term rental apartment unito. Renter occupancy is much more wldespread than in the city as a whole, and rent is generally low throughout the area.

2 Tbid. Page 22. 3 Portland City Planning Commission, Portland's Residential Areas, October, 1965 , University of Oregon Student Interns, A Look at Southeast Portland Mid 1968: Report \#1, July 1968.

* Part of the discrepancy is probably accounted for by differing evaluative criteria. 
The availability of relatively inexpensive shelter makes the area attractive to low-incone families and individuals, most of whom move out as soon as they are able. The 1968 University of Oregon survey cited - earlier in a footnote found that $43 \%$ of all families planned to move sometime within the next five years, and that $85 \%$ of those families with heads of household under 35 years of age were planning to move. In addition, it appears that those families and individuals trapped in limited economic situations, engage in a considerable amount of intra-area mving, the reasons for which would only be speculative.

The effects of this high rate of population turnover are far-reaching. It appears that the PACT area is serving as a holding area for 1 ts residents, significant numbers of whom are composed of the aged, of welfare famlies, of alienated youth, of newcomers to the city who have not established themselves, and of anyone else who cannot, for financial reasons or otherwise, live elsewhere. There is little that is attractive about the area, except that it is "close in" and rent is low. It is a rather arbitrarily defined geographical area, in which living conditions are somewhat less than conducive to human interests, inhabited by a large number of people whose lives in the area are characterized by poverty, alienation, and anomie, and who are surrounded by all the problems, individual and social, typically associated with life under such conditions. We would refer the reader interested in statistics to Appendix $B$ for factual information relative to some of these problems.

Perhaps the facts of life under such conditions as are found in the PACT target area weigh most heavily on children. It is difficult 
to make such a statement with any certainty. But there are conditions In addition to those already outlined which do bear directly on the Iives of children. Recreational facilities, for instance, are oadly lacking. There are only five small parks actually within the boundaries of the target area. None are extensively equipped to meet the needs of children. They are widely scattered, and because of the area's traffic pattems, access to them is something less than safe and easy. (See Figure 1, Appendix A.)

The area's schools also share the problem of safe accesaibility, for the same reasons. In addition, the schools themselves are typically, though not entirely, located in outdated buildings with limited space and play facilities. We are not qualified to make judgments on the quality of the educational experience in these schools but it does seem safe to suggest that because of the socioeconomic characteristics of the area's population, its schools might have some difficulty providing a conslatent, enriching educational program. School district statigtics for 1968-69 contain some startling figures: $29 \%$ of the elementary school children were from low-income families; $27 \%$ from one-parent households; 16.57 from welfare families; and the rate of student turnover ranged Iram a low of $19 \%$ at Richmond School to a whopping $46 \%$ at Buckman, averaging out to $27 \%$ for all area public schools. (See Tables 7 and 8, Appendix B.) 
METHODOLOGY AND ANALYSIS OF DATA

The primary objective of the study was, of course, to get some idea of the dimensions of the assumed need for children's mental health services in the PACT target area. Earlier research ${ }^{4}$ had found a dearth of such services statewide, but our aim was to select a sample population and assess the need on a sub-community basis. In addition, Mr. Tovey was also interested in some related ideas. For example, it was his feeling that the referrals coming out of the area to existing service agencies far under-indicated the need for services, and that, if this proved to be true, it might be due to disenchantment with the existing services on the part of referring persons. A number of reasons for such were hypothesized, including excessive walting periods, inappropriateness and/or incompleteness of services actually obtained, and so on. He was thus interested in finding out if the referring persons were satisfied with existing referral processes and services and, if not, what improvements they felt should be made.

A sample survey approach involving those people who would be likely to make referrals of children for mental health services seemed most appropriate for getting at the information which was desired, and in the early stages of planning a great deal of thought was devoted to determining the nature of our sample population. All possible sources of referrals were considered, Irom public health nurses to welfare caseworkers, doctors and the schools. The final decision was to rely entirely on the schools

4 Greenleigh Association, Inc., "Child Welfare Needs and Services in Oregon," A Report to the Governor's Child Welfare Study Comittee, N.Y., 1968, p.263. 
and specifically, on the classroom teachers. There were two principle reasons for this decision: first, the schools lend themselves well to consiatent sampling procedures; second, the schools are the one socisl institution which commands contact with virtually all members of the population with which we were concerned, i.e., elementary school aged children (and, indirectly, their families), and which keeps records. The school statistice which were referred to earlier illustrate the importance of this last point: in a sense, the schools provide a window through which the observer is able to see into the lives of the otherwise alienated, hard-to-reach, out-of-contact families of the area.

It was thus assumed that the vast majority of referrals of children for mental health services would originate in the schools, and that the classroom teachers, in every day direct contact with the children, would typically be responsible for the initiation of the referral process. Following this decision, we turned our attention to sampling procedure, making the decision to use a guided interview format rather than mailed questionnaires or some other approach. This personal approach, though time consuming, would hopefully eliminate the possibility of delayed response or failure to respond. In addition, it was hoped that personal contact would provide an opportunity to acquaint school personnel with the purpose and possible results of the practicum effort and involve them to a greater extent. Finally, our approach would set the stage, in a sense, for subsequent follow-up contacts in the sampled schools by mentel health professionals.

A series of twelve questions were prepared as the core of the interview format; after consultation with researohera silled in date collection 
the number was pared down to seven to facilitate interview process and to reduce the amount of time required from each teacher. Other content revigions were made pertinent to maintaining flow and focus within the seven-question framowork. The seven questions in finalized form appear below: *

1. How many atudents in your classroom?

2. Please estimate the number of students in your claseroom who you feel would benefit from some form of mental health oervice (e.g., diagnosis, counseling, guidance, therapy, etc.)

These youngsters may be seen as:

a. withdrawn-anxious

b. immature-inadequate

c. aggressive-hostile

3. How many students have you referred for mental health services (e.g., disgnosis, counseling, guidance, therapy, etc.) during the current ochool year?

4. If there is a discrepancy between the responses given to \#2 and \#3 above: how would you explain the fact that only children were referred for mental health services if were seen as needful?

5. Are you satisfied with the results of referrals that have been made? As an example could you describe the process of the last referral you made?

6. Do you feel it would be advantageous to have a children's mental health service agency located in the PACT target area? Yes No

7. Ideally, what kind of services should such an agency provide to meet the needs which you see?

\footnotetext{
*Te entire interview format in the form in which it was used appears as Appendix $D$.
} 
As can be seen, the firat three questions in the interview format were designed to yield numerical responses for statistical analyois. The remaining questions were designed to yield subjective, anecdotal responses which would carry weight in their own right but which would also, it wes hoped, lend meaning and life to the numerical responses obtained from questions two and three.

We were concerned about the multiplicity of posaible definitions of the term "mental health service," which appears in questions two and three, and in an effort to eliminate confusion over this it was decided to suggest a variety of such services, as was done in both questions. We were also particularly concerned about the teachers' ability to Identify those children in their classrooms who might be in need of mental health services. Wishing to avold or reduce the possibility of the teachers identifying only those children who are "problems," such as the acting out child, it was decided to suggest the three categories of behavior which are a part of question two. These categories were defined by Quay, Morse; and Cutler as the three most commonly' seen pathological patterns in emotionally dieturbed children. 5

In the interviews the teachers were advised that they were not expected to differentiate between these categories and that they were offered only to assist them in thinking about their pupils and responding to this question. Parenthetically, reviewing the actual interviewing process in retrospect lesds us to feel justified in our inclusion of these examples.

5

Quay, Herbert; Morse, William C.; Cutler, Richard L.; "Personality Patterns of Pupils in Special Classes for the Enotionally Disturbed," in Exceptional Children, volume 32, January, 1966, p. 297. 
Sempled teachers often indicated clarification upon mention of the three generalized categories, and they did seem to assist the teachers in thinking about their pupils: a amall number, for example, observed that some pupils occasionally manifest behavior that is characteriatic of a combination of the suggested categories.

Question four was designed to get at the assumed discrepancy between the actual need for bervices and the need as indicated by referrals to existing agencies. In practice this question turned out to be mach more directly related to question five than was expected. In regard to question five, the decision to request a description of the process of the last referral made was based on the belief that emotional involvement with the last referral would still be at a high level, assuming the referral was made at all recently, and descriptive responses to this question would thus be more potent.

Questions six and seven speak pretty much for themselves; they were designed to get the opinions of the people who make the referrals regarding the needs tha't they see, and ways that they feel these needs can best be met.

A determination remained to be made regarding the size of the sample population before the actual survey could be conducted. On the advice of a statistician a preliminary survey was prepared, consiating of the first three questions from the interview format administered to three teachers in three of the area's ten elementary schools, in order to get an idea of how consistent responses would be and, thus, what size sample population would be necessary. Arrangements were made with the respective school principals and the test survey was conducted with the nine classroom teachers. 
The degree of cooperation from the schools was generally good once the principals reached a clear understanding of our intent and purpose, and most of the teachers seemed eager to talk with someone about the emotional problems that are manifested in their classrooms.

The results from the test survey showed a high degree of response consistency within each school but wide differences between schools. Accordingly, It was decided that all ten of the elementary schools in the area would have to be sampled. The high rate of intra-school reaponse consistency indicated that a minimm $10 \%$ classroom sample from each school would be sufficient to yield valid data. Since the number of classrooms in the ten schools ranges from a low of four to a high of twenty-nine, a sample of two classrooms was drawn from those schools with less than twenty classrooms and four classrooms Prom those with twenty or more, in order to achieve a minimu 10\% proportional allocation weighted in favor of the larger achools. The complete breakdown 18 given in Appendix C, school by school.

In both the preliminary and the full-scale surveys, intial contact with the schools was made by telephone and appointments with the principals were arranged. Our intent and purpose was then explained to the principals' satiofaction, following which interviews with teachers were arranged. The teachers were also informed of what we were about before getting into the actual interview format, which was informalized in practice, and they were told that their names would not be used in the report of the practicum.

Also, in both the preliminary and the full-scale surveys, selection of aample teachers was left up to the respective school principals. In doing so, a technical error of unknown seriousness was combitted: 
Inviting principal bias and virtually eliminating complete randomization of the ample. In retrospect, we attribute this error to our eagerness to gain the cooperation of the principals. There seems to be a wideopread general attitude among the helping professionals that the public sohools are a closed system, suspicious of outside intervention, and the reaponse of the principals to our initial approaches, bore this out to varying degrees. So, in part, to allay the defensiveness of the principals, and in part unwittingly, complete randomization was sacrificed. What remained was a semblance of randomization: at most of the schools, whichever teachers happened to be free during the time of our visits, were interviewed. At some, several were free and the requisite number were randomily selected on the spot by the interviewer.

Short of repeating the study, it does not appear possible to speculate on the pervasiveness and/or direction of principal bias in the results, if, indeed, there was any. It is the authorg' feeling that in spite of this possibility, the dats obtained from the ten sampled schools, inevitably validates the primary assumption of this practicum effort, i.e., that a critical need exists for expanding and improving mental health services available to children in the PACT target area. The raw data obtained in response to questions two and three is contained in the table on the following page, and the analyaes of this data on the following two pages. The raw data alone suggests a considerable need for children's mental health services, and the projected figures are staggering. 
TABLE I - RESPONSES TO QUESTIONS TWO AND THREE

Raw data

\begin{tabular}{|c|c|c|c|c|c|}
\hline \multirow[b]{2}{*}{ School } & \multicolumn{3}{|c|}{ Classrooms sampled } & \multirow{2}{*}{$\begin{array}{l}\text { Children geen by the } \\
\text { teacher as needing } \\
\text { some form of mental } \\
\text { health service }\end{array}$} & \multirow{2}{*}{$\begin{array}{l}\text { Children } \\
\text { referred for } \\
\text { such service }\end{array}$} \\
\hline & number & grade & size & & \\
\hline Abernethy & 4 & $\begin{array}{l}2 \\
1 \\
4 \\
6\end{array}$ & $\begin{array}{l}24 \\
16 \\
22 \\
28\end{array}$ & $\begin{array}{r}20 \\
9 \\
11 \\
8\end{array}$ & $\begin{array}{l}1 \\
2 \\
4 \\
5\end{array}$ \\
\hline Brooklyn & 2 & $\begin{array}{l}6 \\
7\end{array}$ & $\begin{array}{l}33 \\
30\end{array}$ & $\begin{array}{l}13 \\
10\end{array}$ & $\begin{array}{l}6 \\
1\end{array}$ \\
\hline Buckman & 4 & $\begin{array}{l}7 \\
8 \\
8 \\
7\end{array}$ & $\begin{array}{l}19 \\
21 \\
19 \\
19\end{array}$ & $\begin{array}{r}3 \\
15 \\
15 \\
9\end{array}$ & $\begin{array}{l}0 \\
3 \\
4 \\
3\end{array}$ \\
\hline Edwards & 2 & $\begin{array}{l}1 \\
2\end{array}$ & $\begin{array}{l}22 \\
24\end{array}$ & $\begin{array}{r}3 \\
10\end{array}$ & $\begin{array}{l}3 \\
2\end{array}$ \\
\hline Kerns & 2 & $\begin{array}{c}4 \\
1-2\end{array}$ & $\begin{array}{l}24 \\
20\end{array}$ & $\begin{array}{l}6 \\
5\end{array}$ & $\begin{array}{l}5 \\
3\end{array}$ \\
\hline Richmond & 2 & $\begin{array}{l}5 \\
4 \\
3 \\
2\end{array}$ & $\begin{array}{l}31 \\
28 \\
28 \\
24\end{array}$ & $\begin{array}{r}5 \\
0 \\
3 \\
10\end{array}$ & $\begin{array}{l}0 \\
0 \\
0 \\
4\end{array}$ \\
\hline Suningalde & 4 & $\begin{array}{l}5 \\
1 \\
\mathrm{~K} \\
6\end{array}$ & $\begin{array}{l}28 \\
29 \\
30 \\
27\end{array}$ & $\begin{array}{r}8 \\
13 \\
12 \\
4\end{array}$ & $\begin{array}{l}4 \\
7 \\
8 \\
2\end{array}$ \\
\hline St. Prancis & & $\begin{array}{l}7-8 \\
5-6\end{array}$ & $\begin{array}{l}19 \\
17\end{array}$ & $\begin{array}{r}5 \\
14\end{array}$ & $\begin{array}{l}2 \\
2\end{array}$ \\
\hline St. Philip & 2 & $\begin{array}{l}7 \\
6\end{array}$ & $\begin{array}{l}29 \\
19\end{array}$ & $\begin{array}{l}5 \\
3\end{array}$ & $\begin{array}{l}0 \\
0\end{array}$ \\
\hline St. Stephen & 2 & $\begin{array}{l}5 \\
1\end{array}$ & $\begin{array}{l}37 \\
27\end{array}$ & $\begin{array}{l}12 \\
10\end{array}$ & $\begin{array}{l}2 \\
2\end{array}$ \\
\hline
\end{tabular}


TABLE II - ANALYSIS OF RESPONSES TO QUESTION TWO

\begin{tabular}{|c|c|c|c|c|c|c|c|c|c|c|}
\hline , & 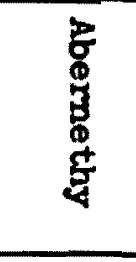 & 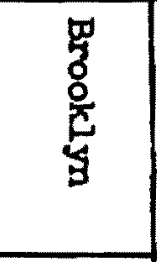 & $\begin{array}{l}\text { 安 } \\
\frac{5}{5} \\
\frac{1}{5}\end{array}$ & $\begin{array}{l}8 \\
\frac{8}{2} \\
2 \\
\frac{2}{0}\end{array}$ & 蛋 & 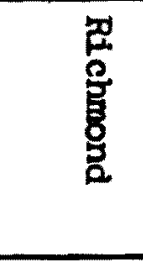 & 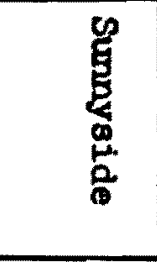 & 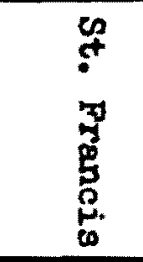 & $\underbrace{\infty}_{0}$ & 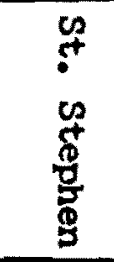 \\
\hline $\begin{array}{l}\text { Mean number of children per } \\
\text { sampled classroom identified } \\
\text { by the teachers as needing } \\
\text { some form of mental health } \\
\text { service }\end{array}$ & 12 & 11.5 & 10.5 & 6.5 & 5.5 & 4.5 & 9.3 & 9.5 & 4 & 11 \\
\hline $\begin{array}{l}\text { Projected total number of } \\
\text { children in all classrooms } \\
\text { who would be identified by } \\
\text { their teachers as needing } \\
\text { some form of mental health } \\
\text { service, based on the mean } \\
\text { for the sampled classrooms }\end{array}$ & 240 & 161 & 220.5 & 71.5 & 44 & 130.5 & 212.8 & 38 & 32 & 88 \\
\hline $\begin{array}{l}\text { Projected total number of } \\
\text { children so identified } \\
\text { expressed as a percentage } \\
\text { of the total school } \\
\text { population }\end{array}$ & $52 \%$ & 468 & $42 \%$ & 238 & 228 & $16 \%$ & $34 \%$ & $40 \%$ & $17 \%$ & 338 \\
\hline $\begin{array}{l}\text { Variance in sampled } \\
\text { classrooms }\end{array}$ & 30 & 4.5 & 99 & 24.5 & .5 & 53 & 50.75 & 40.5 & 2 & 2 \\
\hline $\begin{array}{l}\text { Standard deviation in } \\
\text { sampled classrooms }\end{array}$ & 5.5 & 2.12 & 9.95 & 4.95 & .71 & 7.29 & 7.12 & 6.37 & 1.41 & $1.4]$ \\
\hline $\begin{array}{l}\text { Coefficient of } \\
\text { variation }\end{array}$ & $46 \%$ & $18 \%$ & $95 \%$ & $76 \%$ & $13 \%$ & $62 \%$ & $77 \%$ & 688 & $35 \%$ & $13 \%$ \\
\hline
\end{tabular}


TABLE III - ANALYSIS OF RESPONSES TO QUESTION THREE

\begin{tabular}{|c|c|c|c|c|c|c|c|c|c|c|}
\hline & 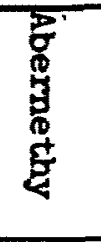 & 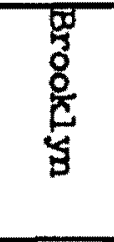 & 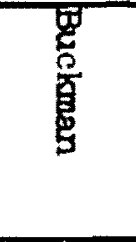 & $\begin{array}{l}\frac{\pi}{0} \\
\frac{2}{2} \\
\frac{2}{2} \\
\frac{0}{0}\end{array}$ & 穿 & 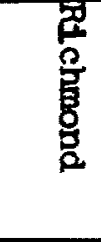 & 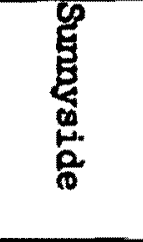 & 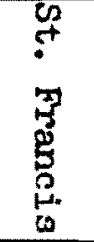 & 驾 & 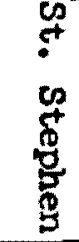 \\
\hline $\begin{array}{l}\text { Mean number of children per } \\
\text { sampled classroom already } \\
\text { referred by the teachers for } \\
\text { some form of mental health } \\
\text { service }\end{array}$ & 3 & 3.5 & 2.5 & 2.5 & 4 & 1 & 5.3 & 2 & 0 & 2 \\
\hline $\begin{array}{l}\text { Projected total number of } \\
\text { children in all classrooms } \\
\text { who have already been re- } \\
\text { ferred for some form of } \\
\text { mental health service, } \\
\text { based on the mean for the } \\
\text { sampled classrooms }\end{array}$ & 60 & 49 & 52.5 & $27 \cdot 5$ & 32 & 29 & 121.9 & 8 & 0 & 16 \\
\hline $\begin{array}{l}\text { Projected total number of } \\
\text { children already referred, } \\
\text { expressed as a percentage } \\
\text { of the total school pop- } \\
\text { ulation }\end{array}$ & 1386 & $14 \%$ & $10 \%$ & 98 & $16 \%$ & $4 \%$ & 20,6 & 88 & 0 & $6 \%$ \\
\hline $\begin{array}{l}\text { Projected total number of } \\
\text { children already referred, } \\
\text { expressed as a percentage } \\
\text { of the projected total } \\
\text { identified as needing } \\
\text { some form of mental health } \\
\text { service }\end{array}$ & 258 & $30 \%$ & $24 \%$ & $38 \%$ & $73 \%$ & 228 & $57 \%$ & $21 \%$ & 0 & $18 \%$ \\
\hline $\begin{array}{l}\text { Variance in sampled } \\
\text { classrooms }\end{array}$ & 3.3 & 12.5 & 9 & .5 & 2 & 4 & 7.6 & 0 & 0 & 0 \\
\hline $\begin{array}{l}\text { Standard deviation in } \\
\text { sampled classrooms }\end{array}$ & 1.8 & 6.3 & 3 & .7 & 1.4 & 2 & 2.8 & - & - & - \\
\hline
\end{tabular}


Because there does not appear to be a significant correlation between size of classroom and number of children identified by the teacher as in need of some form of mental health service (see Table I), classroom size was disregarded in the analysis of the data from questions two and three. Plainly, school teachers are not diagnosticians and these figures are largely dependent on their understanding and perception of mental health, which was expected, and on their feelings about the ways in which classroom behavior problems, however defined, should be dealt with. For example, the one teacher in the sample who did not identify any of his pupils as in need of services told the interviewer frankly that he believes such problems should be dealt with only in the classroom. On the other side of the coin, the possibility cannot be ruled out that some of the extremely high responses to question two may be partly accounted for by similar but opposite reasons.

At any rate, the responses to this question were almost uniformy higher than expected; in fact, they are almost alarming. Expressed as percentages, the projected number of children in each school who might be Identified by their teachers as in need of some form of mental health services ranges from a low of $16 \%$ at Richmond School to a high of $52 \%$ at Abernethy. The projected mean number of these children in each of the 146 classrooms in the ten area schools is 8.48. In plain figures, this represents almost 1240 children out of a total area school population of 3847. See Table II for individual school figures. Unfortunately, the high degree of response consistency within schools which was found in the preliminary survey proved lacking in a majority of 
the schools in the full-scale survey. This resulted in less than impressive reliability in some cases, reflected in high degrees of variance and cormaratively large standard deviations. Incressing the size of the sample drawn from each of the schools would probably have redused the variance, but on the basis of the preliminary aurvey it appeared that a ten percent sample would be adequate. If the study were to be repeated, the best policy might be to make an optimal allocation of the sample, concentrating on those schools which demonstrated the greatest variance rather than on the larger schools.

The central point which remains in spite of questions regarding validity is that even the minimum figures still indicate an enormous need, and the responses to question three clearly demonstrate that in the face of this need, most classroom teachers are not making the referrals that they would like to. Within schools, the highest rate of referral of children identified as needing help was $73 \%$ at Kerns School. This rate is considerably higher than the rate at most of the other schools - the average for all ten of the schools is only 31\%. See Table III for the complete figures.

The sampled teachers' responses to question four begin to get at some of the reasons for this rather large discrepancy. Some teachers answered this question in more than one way, but the single most common response was that the necessary services were simply not available. Seventeen of the twenty-eight sampled teachers made this comment. Some of the ways in which it came reflect their anguish: "Only so much help is available and we must make a choice as to those most in need of help;" "I only refer the most severe - those who are really disruptive;" "Only a few can be attended to with the services presently available," and so on. A number of the 
teachers responding in this way indicated that they looked within the school system for the services - to school social workers and psychologists - and some were quite blunt in their appraisal of the aituation. One referred to "non-recognition of the need for mental health care facilities among school personnel;" others simply pointed out that there were too many problems in their schools for one part-time social worker in the achool to handle.

The second most frequent response to question four was that the teachers attempted to deal with problem children in their classrooms as much as possible. Seven teachers made this response in slightly varying ways. In same cases it was directly related to the idea of services being unavailable anyway: "I try to work with the child in the classroom until the problem reaches proportions I no longer can handle;" "If extensive services were available some...would be referred." In other cases, the teachers seemed to genuinely feel that a part of their responsibility was to deal with behavioral problems in the classroom by themselves. Clearly, the teachers themselves do not agree on the scope of their duties. It would be interesting to define the point at which the average classroom teacher would or should "give up" on a problem child. It appears that this has implications for classroon management as well as delivery of services.

Seven teachers also responded to question four by pointing out that parents in one way or another failed to cooperate. One noted that "a majority of parents do not accept the fact that a child needs help." Another noted that "parents are not favorable to such programs." One stated 
frankly that she didn't know how to approsch parents."

Two teachers indicated other measures had been taken to ameliorate identified problems short of referral, such as parent-teacher conferences, and in two otber cases miscellaneous reasons not relevant to this study were given to explain discrepancies between the number of children identified as needing help and the number referred.

Generally, the responses obtained to question five were directly related to those obtained to question four, although a considerable amount of ambivalence was expressed, perhaps because this was a two-part question. It was non-applicable for seven of the teachers, six of whom have not made any referrals this year. For the teachers who were able to respond, eight expressed satisfaction with the results of their referrals so far, eleven expressed dissatisfaction, and two were ambivalent in regard to the "yes or no" part of the question.

Anecdotal responses to the second part of question five varied widely. Of the eight teachers who expressed satisfaction with the results of their referrals, seven had made the referrals to school social workers formally or informally, and had generally carried out a plan involving the student, the parents and the teacher in a conference with or without the social worker's direct participation. In most of these cases, the social worker was involved, particuiarly in dealing with the parents, and the problem situation evidently was ameliorated to the teacher's satisfaction without necessitating further referral of the child for professional help. The eighth satiafied teacher had made the referral to the Children's Mental Health Clinic, where an evaluation was conducted and follow-up planned. 
The eleven teachers who expressed dissatisfaction with the results of their referrals had a variety of reasons for feeling as they did. Four felt that waiting periods were too long because of the strain on existing services. Seven could see little results because, while conferences and evaluations may have been held, in three cases parents had failed to follow up on recomendations and in four others there was no professional follow-up. Parenthetically, one of these latter instances involved a child seen by the Children's Mental Health Clinic. The two remaining dissatisfied teachers simply did not see any remission of symptoms and one expressed the feeling that the child in question had been in such a poor home situation for so long he "apparently is now hopeless."

The two teachers who were ambivalent in regard to the "yes or no" part of question five had different ressons for feeling as they did. One had made a referral to the school social worker and was unoure as to whether the steps taken had been adequate. The other had made a referral to the Children's Mental Health Clinic and, while impressed with the evaluation, was disappointed that no follow-up was available.

The sampled teachers were unanimous in their affirmative reaponse to question six, "Do you feel it would be advantageous to have a children's mental health service agency located in the PACT target area?" One prevalent comment from the respondents concerned the transportation issue involved in utilizing available mental health resources. Several teachers cited specific examples of one-parent households where transporting a child to an agency involved baby sitting details for siblings and lengthy bus rides with transfers for those parents without automobiles. (See Figure 2, Appendix A.) 
Generally, the teachers felt that a resource within the neighborhood would enhance the possibility of the problem children in their classrooms being accomodated by a service agency. Further, they expressed the feeling that they, as referring sources, would foel closer to the helping source; iroplying that they currently fael isolated or alienated from professional mental health personnel and the "helping" process. In this vein, many of the teachers pointed out that they would very much like to be included in the process aince they see the child so many hours during the week and are genuinely concerned. Some of the teachers stated they could learn to be helpful where they felt helpless now.

Question seven, requesting the teachers' opinions on the kinds of service an agency should provide to meet the needs which they see, prompted several responses that were common anons a high percentage of the sample group. The responses moat commonly mentioned included: 1) individual counseling or therapy; 2) extensive involvement by the parents in the therapeutic process; 3) optimum teacher involvement to employ the classroom aetting as a reinforcing component of therapy; and 4) group therapy activities for both youngeters and parents.

In citing the above recommendations many of the cooperating teachers verbalized the opinion that they were only asking for a measure of relief as they have so often done in the past concerning this issue. One teacher caustically said, "Frankly, I don't know why I'm even answering your questions; I'vo done this a hundred times before and nothing's happened. I guess I'm hoping for the impossibla." 
Another suggestion from several respondents concermed "immediate" or "emergency" mental health service available on call. Several instances were cited where children became physically uncontrollable or exhibited some extreme emotional crisis in the classroom and no mental health resource was readily available to assist.

Other less frequent recomendations for mental health services elicited by question seven were: physical examinations to determine brain damage, otc.; recreational activities with peer groups; training teachers to relate more effectively with parents of disturbed youngsters to facilitate and expedite treatment and participation; and emphasis on including withdrawn and depressed children in treatment since they are less likely to be referred than "acting out" children.

In answering question seven, the teachers repeatedly emphasized that they were not "blaming" anyone for the lack of mental health services; on the contrary, they sympathized with the overworked mental health professionals. A few drew an analogy between the teaching profession and the mental health professions, pointing out that both are understaffed to meet the demands on them and need relief in terms of manpower. However, they eventualiy indicated that a lack of mental bealth resources ultimately forced them to handle emotional problems in the classroom for which they. are not adequately prepared.

SUMMARY AND CONCLUSIONS

This was an exploratory study of the mental health needs of children in the PACT target area, an economically and socially impoverished inner-city 
area. Conducted on a grass-roots level, it involved taking the problem to those people most directly in contact with it - classroom teachers in the area's ten elementary public and parochial schools. A guided interview format was devised and utilized in personal contacts with the teachers, who were asked to define the need for such services as they saw it in their own classrooms, both as to size and to kind. They were also asked, in essence, what they were doing about it and what they would like to see done about it. The results were staggering. Projections of the responses of twentyeight classroom teachers - a $10 \%$ minimum sample in each of the ten schools suggest that almost one-third (1240) of the area's elementary school aged children might be identifled by their teachers as in need of some form of mental health service.

In the face of this overwhelming need only a comparative trickle of referrals for professional help comes out of the classrooms. The reasons for this vary somewhat, but the most frequently occurring one was that the teachers do not feel that the necessary services are avallable. They seem to look first within the school system for the help which they need, and in most cases, the system fails to respond. There are a few notable exceptions. Four of the sampled teachers who expressed satisfaction with the results of referrals they have made, teach at the same school - one which has a full-time social worker who has managed to take charge and ameliorate some of the problems seen by the teachers. The over-all picture, however, is bleak. While almost all of the schools have part-time social work help, the teachers point repeatedly to the fact that this is simply not adequate to meet the need. 
There are two principal agencies in the community which relate to the mental health needs of children on an out-patient basis - the Child Psychlatry Department at the Untversity of Oregon Medical School and the Child Guidance Clinic. Both of these agencies serve vast catchment populations and are deluged with requests for service. Waiting periods are long and manpower is strained. In the period from July, 1969, to March 15, 1971, only 34 children from the PACT target area were seen at the Medical School. 39 were seen at the Child Guidance Clinic so far during the current school year.

The teachers' frustration in this situation was clear. They talked about trying to manage disturbed children in the classroom and the need to set priorities, referring only the most severe cases for outside help. Complicating this picture, however, is the fact that quite a few of the teachers seem to feel that management of problem behavior in the classroom is a part of their duties. This is a position which is reinforced by the fact that thefe are few alternatives.

Because of the possibility of principal bias in selection of sampled teachers, and because of wide variation in response consistency within a few of the sampled schools, there is sone question regarding the validity of some of the data obtained in this sturty. However, in spite of these questions, the authors feel that the primary objective of the practicum effort has been achieved - a considerable need for children's mental health services in or convenient to the PACT target area, has been demonstrated and the area's elementary school teachers, as the primary referring agents for such services, have supplied suggestions for ways in which the need can be better met. 
APPENDIX A Maps 



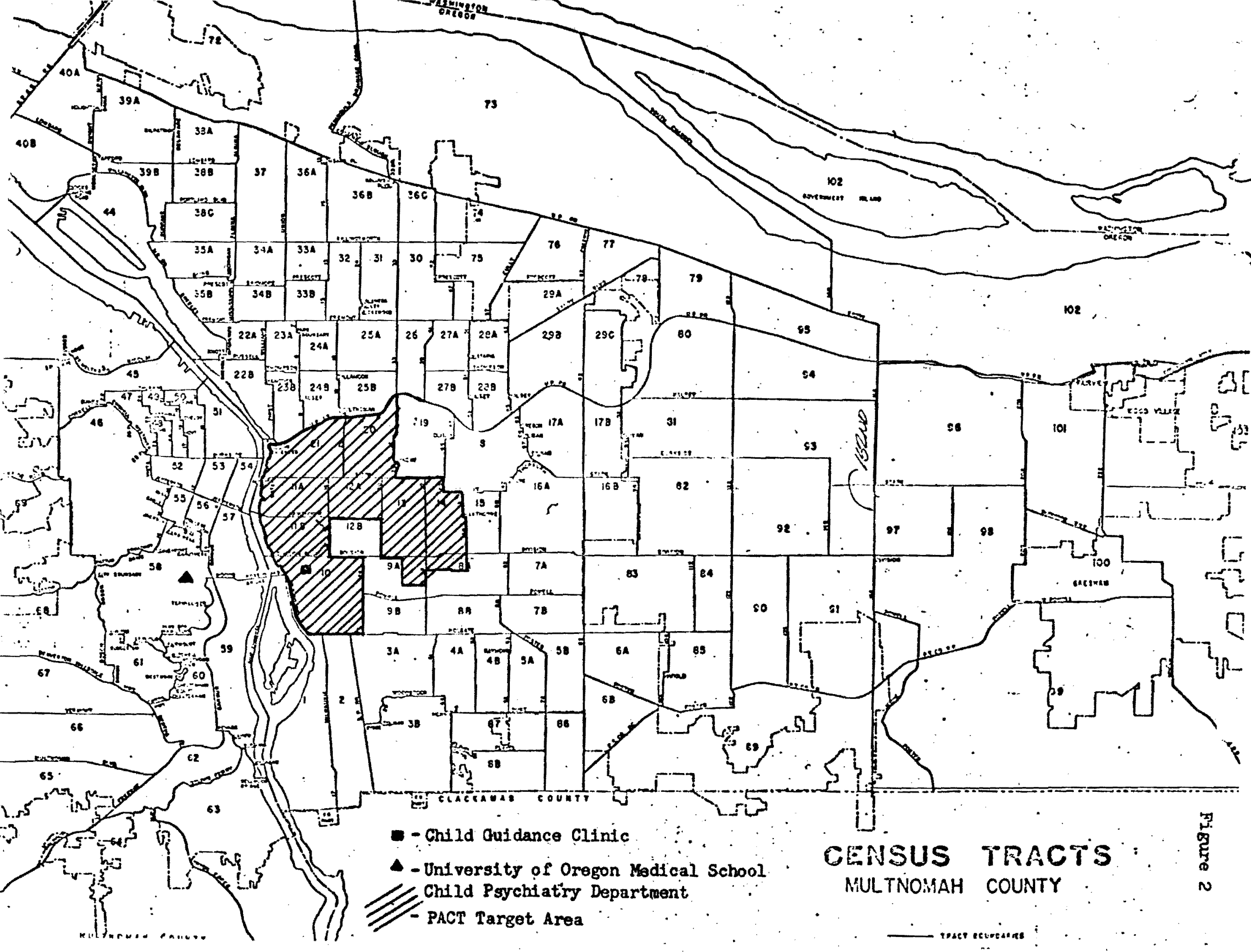


APPENDIX B

Statistics on Some

PACT Area Social Problems 
TABLE - 1

\begin{tabular}{|c|c|c|c|}
\hline \multicolumn{2}{|c|}{ REPORTED CRTMES - 1969} \\
\hline $\begin{array}{c}\text { PACT AREA CENSUS } \\
\text { TRACTS }\end{array}$ & $\begin{array}{c}\text { ESTIMATED } \\
\text { POPULATION } \\
1969\end{array}$ & $\begin{array}{c}\text { TOTAL REPORTED } \\
\text { OFFENSES }\end{array}$ & $\begin{array}{c}\text { OFFENSES PER } \\
1000 \\
\text { POPULATION }\end{array}$ \\
\hline $1 / 4$ of 8A & 1293 & 104 & 80.4 \\
\hline $2 / 3$ of 9A & 3319 & 324 & 97.6 \\
\hline 10 & 6700 & 922 & 137.6 \\
\hline $11 \mathrm{~A}$ & 2100 & 814 & 387.6 \\
\hline $11 B$ & 2180 & 364 & 166.9 \\
\hline $12 A$ & 4980 & 574 & 115.2 \\
\hline 13 & 7680 & 871 & 113.4 \\
\hline 14 & 5430 & 510 & 93.9 \\
\hline 14 & 4173 & 527 & 126.2 \\
\hline POTAL PACT AREA & 40645 & 1022 & 366.3 \\
\hline PORT OF & 2790 & 6032 & 148.4 \\
\hline
\end{tabular}

SOURCE: Crime Statistics by Census Tract,

Portland Bureau of Police, 1969. 
TABLE - 2

\begin{tabular}{|c|c|c|c|}
\hline \multicolumn{4}{|c|}{ JUVENILES REFERRED FOR DELINQUENCY - 1969} \\
\hline $\begin{array}{c}\text { PACT AREA } \\
\text { CENSUS TRACTS }\end{array}$ & $\begin{array}{l}\text { ESTIMATED } \\
\text { JUVENILE } \\
\text { POPULATION }\end{array}$ & $\begin{array}{l}\text { NUMBER OF } \\
\text { JUVENILES } \\
\text { REPERRED FOR } \\
\text { DELINQUENCY }\end{array}$ & $\begin{array}{l}\text { NOMBER OF } \\
\text { REFERRALS PER } \\
1000 \text { JUVEIIILE } \\
\text { POPULATION }\end{array}$ \\
\hline $1 / 4$ of $8 \mathrm{~A}$ & 418 & 9 & 21.5 \\
\hline $2 / 3$ of $9 A$ & 1,087 & 24 & 22.0 \\
\hline 10 & 1,972 & 61 & 30.9 \\
\hline$I I A$ & 296 & 14 & 47.2 \\
\hline $11 B$ & 654 & 10 & 15.2 \\
\hline $12 A$ & 998 & 30 & 30.0 \\
\hline 13 & 2,189 & 56 & 25.5 \\
\hline 14 & 1,552 & 38 & 24.4 \\
\hline $2 / 3$ of 20 & 864 & 23 & 26.6 \\
\hline 21 & 629 & 27 & 42.9 \\
\hline IOTAL PACT AREA & 10,659 & 292 & 27.3 \\
\hline $\begin{array}{l}\text { CITY OF } \\
\text { PORTLAND }\end{array}$ & 116,275 & 2,674 & 22.9 \\
\hline
\end{tabular}

SOURCE: Number of Children Referred for Delinquency by Census Tract, Multnomah County Juvenile Court, 1969. 
TABLE - 3

\begin{tabular}{|c|c|c|c|}
\hline \multicolumn{4}{|c|}{ PUBLIC HEALTH NURSE VISITS - 1969} \\
\hline $\begin{array}{l}\text { PACT AREA CENSUS } \\
\text { TRACTS }\end{array}$ & $\begin{array}{c}\text { ESTIMATED } \\
\text { POPULATION } \\
1969 \\
\end{array}$ & $\begin{array}{l}\text { NUMBER OF } \\
\text { PATIFNT } \\
\text { VISITS } \\
\end{array}$ & $\begin{array}{l}\text { PATIENTS } \\
\text { PER } 1000 \\
\text { POPULATION }\end{array}$ \\
\hline $1 / 4$ of $8 \mathrm{~A}$ & 1293 & 22 & 17.0 \\
\hline $2 / 3$ of $9 A$ & 3319 & 71 & 21.3 \\
\hline 10 & 6700 & 182 & 27.1 \\
\hline $12 \mathrm{~A}$ & 2100 & 139 & 66.1 \\
\hline 118 & 2180 & 71 & 32.5 \\
\hline $12 \mathrm{~A}$ & 4980 & 102 & 20.4 \\
\hline 13 & 7680 & 249 & 32.4 \\
\hline 14 & 5430 & 103 & 18.9 \\
\hline $2 / 3$ of 20 & 4173 & 78 & 18.6 \\
\hline 21 & 2790 & 121 & 43.3 \\
\hline TOTAL PACT AREA & 40645 & 1138 & 27.9 \\
\hline $\begin{array}{l}\text { CITY OF } \\
\text { PORTLAND }\end{array}$ & 377800 & 8446 & 22.3 \\
\hline
\end{tabular}

SOURCE: Summary of Total Patients Visited by

Nurse In Each Census Tract Report Year 1968-1969,

Portland-Multnomah Health Department, 1969. 
TABLE - 4

\begin{tabular}{|c|c|c|c|c|}
\hline \multicolumn{5}{|c|}{ MNFANT MORTALITY - 1969} \\
\hline $\begin{array}{l}\text { PACT AREA CENSUS } \\
\text { TRACTS }\end{array}$ & $\begin{array}{l}\text { RESIDENT LIVE } \\
\text { BIRTHS - } 1969\end{array}$ & $\begin{array}{l}\text { TOTAL RESIDENT } \\
\text { DEATHS } \quad-1969\end{array}$ & $\begin{array}{c}\text { INFANT } \\
\text { DEATHS } \\
1969\end{array}$ & $\begin{array}{l}\text { INFANT } \\
\text { DEATHS } \\
\text { PER 1000 } \\
\text { BIRTHS } \\
\end{array}$ \\
\hline $1 / 4$ of $8 \mathrm{~A}$ & 17 & 15 & 1 & 58.8 \\
\hline $2 / 3$ of $9 A$ & 51 . & 31 & 3 & 58.8 \\
\hline 10 & 134 & 77 & 1 & 7.4 \\
\hline $11 \mathrm{~A}$ & 44 & 57 & 1 & 22.7 \\
\hline $11 B$ & 31 & 38 & 1 & 32.2 \\
\hline $12 \mathrm{~A}$ & 113 & 68 & 5 & 44.2 \\
\hline 13 & 158 & 145 & 4 & 25.3 \\
\hline 14 & 74 & 63 & 3 & 40.5 \\
\hline $2 / 3$ of 20 & 81 & 61 & 2 & 24.6 \\
\hline 21 & 76 & 52 & 1 & 13.1 \\
\hline TOTAL PACT AREA & 779 & 607 & 22 & 28.2 \\
\hline $\begin{array}{l}\text { CITY OF } \\
\text { PORTLAND }\end{array}$ & 6145 & 4889 & 128 & 20.8 \\
\hline
\end{tabular}

SOURCE: Resident Deaths by Portland Census Tracts,

State of Oregon, Department of Health - Vital Statistics, 1969 
TABLE - 5

\begin{tabular}{|c|c|c|c|c|c|}
\hline \multicolumn{6}{|c|}{ IUBERCULOSIS CASES } \\
\hline $\begin{array}{l}\text { PACT AREA } \\
\text { CENSUS } \\
\text { TRACTS } \\
\end{array}$ & $\begin{array}{c}\text { POPULATION } \\
1960\end{array}$ & $\begin{array}{l}\text { TOTAL CASES } \\
1960-1969\end{array}$ & $\begin{array}{l}\text { TOTAL CASES } \\
\text { RATE PER } \\
1000 \text { POP. }\end{array}$ & $\begin{array}{l}\text { CURRENT } \\
\text { ACTIVE } \\
\text { CASES }\end{array}$ & $\begin{array}{l}\text { ACTIVE CASES } \\
\text { RATE PER } \\
1000 \text { POP. }\end{array}$ \\
\hline $1 / 4$ of $8 A$ & 1,259 & 2 & 1.6 & 2 & 1.6 \\
\hline $2 / 3$ of $9 A$ & 3,187 & 3 & .9 & 2 & .6 \\
\hline 10 & 6,433 & 19 & 3.0 & 19 & 3.0 \\
\hline $12 \mathrm{~A}$ & 2,218 & 19 & 8.6 & 19 & 8.6 \\
\hline $11 B$ & 2,351 & 15 & 6.4 & 4 & 1.7 \\
\hline $12 \mathrm{~A}$ & 4,561 & 24 & 5.3 & 24 & 5.3 \\
\hline 13 & 7,681 & 22 & 2.9 & 22 & 2.9 \\
\hline 14 & 5,421 & 5 & .9 & 5 & .9 \\
\hline $2 / 3$ of 20 & 4,010 & 12 & 3.0 & 12 & 3.0 \\
\hline 21 & 3,156 & 32 & 10.1 & 18 & 5.7 \\
\hline $\begin{array}{l}\text { TOTAL PACT } \\
\text { AREA }\end{array}$ & 40,277 & 153 & 3.8 & 127 & 3.2 \\
\hline $\begin{array}{l}\text { CITY OF } \\
\text { PORMLAND }\end{array}$ & 372,676 & 1,876 & 5.0 & 1,087 & 2.9 \\
\hline
\end{tabular}

SOURCES: New Tuberculosis Cases by Census Tracts 1959-1966, Portland

Bureau of Health, 1967.

Tuberculosis - Portland, by Census Tract 1967 ,

Portland Bureau of Health, 1967.

New Cases and Deaths From TB 1968 and 1969,

Portland-Multnomah Health Department, 1969. 
TABLE - 6

\begin{tabular}{|c|c|c|c|}
\hline \multicolumn{4}{|c|}{ TLLEGITIMATE BIRTHS - 1969} \\
\hline $\begin{array}{c}\text { PACT AREA CENSUS } \\
\text { TRACTS }\end{array}$ & $\begin{array}{l}\text { TOTAL RESIDENT } \\
\text { LIVE BIRTHS } \\
1969\end{array}$ & $\begin{array}{l}\text { NUMBER OF } \\
\text { ILLEGITIMATE } \\
\text { BIRTHS } 1969\end{array}$ & $\begin{array}{l}\text { PERCENT OF } \\
\text { BIRTHS } \\
\text { IHLEGITMATE }\end{array}$ \\
\hline $1 / 4$ of $8 A$ & 17 & 3 & 17.6 \\
\hline $2 / 3$ of $9 A$ & 51 & 5 & 9.8 \\
\hline 10 & 134 & 16 & 11.9 \\
\hline $11 \mathrm{~A}$ & 44 & 12 & 27.3 \\
\hline $11 \mathrm{~B}$ & 31 & 5 & 16.1 \\
\hline $12 \mathrm{~A}$ & 113 & 15 & 13.3 \\
\hline 13 & 158 & 22 & 12.9 \\
\hline 14 & 74 & 12 & 16.2 \\
\hline $2 / 3$ of 20 & 81 & 21 & 25.9 \\
\hline 21 & 76 & 24 & 31.6 \\
\hline TOLAL PACT AREA & 779 & 135 & 17.3 \\
\hline $\begin{array}{l}\text { CITY OF } \\
\text { PORTLAND }\end{array}$ & 6145 & 971 & 15.8 \\
\hline
\end{tabular}

SOURCE: Resident Live Births by Race by

Portland Census Tracts,

State of Oregon, Department of Health - Vital Statistics, 1969. 
TABLE - 7

\begin{tabular}{|c|c|c|c|c|c|}
\hline SCHOOL & $\begin{array}{l}\text { TOTAL } \\
\text { ENROLL- } \\
\text { MENT } \\
\text { 1968-1969 }\end{array}$ & $\begin{array}{l}\text { TURNOVER } \\
\text { PERCENT }\end{array}$ & $\begin{array}{l}\text { PERCENT OF } \\
\text { STUDENTS } \\
\text { FROM LOW- } \\
\text { INCOME } \\
\text { FAMILIES* } \\
\end{array}$ & $\begin{array}{l}\text { PERCENT OF } \\
\text { STUDENTS } \\
\text { FROM ONE- } \\
\text { PARENT } \\
\text { FAMULIES* } \\
\end{array}$ & $\begin{array}{l}\text { PERCENT OF } \\
\text { STUDENTS } \\
\text { FROM WELFARE } \\
\text { FAMILIES }\end{array}$ \\
\hline Abernethy & 458 & 28 & 30 & 35 & 25.2 \\
\hline Brooklym & 386 & 30 & 31 & 34 & 19.5 \\
\hline Buckman & 520 & 46 & 63 & 37 & 30.2 \\
\hline Edwards & 299 & 21 & 23 & 24 & 10.7 \\
\hline Kerns & 241 & 31 & 33 & 30 & 15.1 \\
\hline Richmond & 863 & 19 & 25 & 22 & 13.6 \\
\hline Sunnoside & 766 & 27 & 23 & 24 & 18.7 \\
\hline $\begin{array}{l}\text { PACT AREA } \\
\text { AVERAGE } \\
\text { PER SCHOOL }\end{array}$ & 505 & 29 & 33 & 29 & 19 \\
\hline $\begin{array}{l}\text { CITY OF } \\
\text { PORTLAND } \\
\text { AVERAGE } \\
\text { PER SCHOOL }\end{array}$ & 692 & 18.2 & 15 & 17 & 11.1 \\
\hline
\end{tabular}

SOURCES: Building Study in the Portland Public Schools,

School District No. 1, 1967.

Estimated Membership Study 1968-1969,

School District No. 1, 1969.

Students Ages 6-13 in Welfare Families by Elementary School Area,

School District No. 1, 1969.

* Estimate based on census tract statistics 


\begin{tabular}{|c|c|c|c|c|c|}
\hline \multicolumn{6}{|c|}{ PAROCHIAL EILMENTARY SCHOOL STATISTICS - 1968-1969 } \\
\hline SCHOOL & $\begin{array}{l}\text { ROMAL } \\
\text { ENROLLMENT } \\
\text { 1968-1969 }\end{array}$ & $\begin{array}{l}\text { TURNOVER } \\
\text { PERCENT }\end{array}$ & $\begin{array}{l}\text { PERCENT OF } \\
\text { STUDENTS } \\
\text { FROM LOW- } \\
\text { INCOME } \\
\text { FAMLLES }\end{array}$ & $\begin{array}{l}\text { PERCENT OF } \\
\text { STUDENTS } \\
\text { FROM ONE- } \\
\text { PARENT } \\
\text { FAMIILES }\end{array}$ & $\begin{array}{l}\text { PERCENT OF } \\
\text { STUDENTS } \\
\text { FROM WEILARE } \\
\text { FAMILIES }\end{array}$ \\
\hline St. Francis & 111 & 0 & 33.0 & 53.0 & 29.0 \\
\hline $\begin{array}{l}\text { St. Philip } \\
\text { Neri }\end{array}$ & 230 & 0 & 25.6 & 5.2 & 13.0 \\
\hline St. Stephens & 268 & 0 . & 21.4 & 15.3 & 19.0 \\
\hline $\begin{array}{l}\text { PACT AREA } \\
\text { AVERAOE } \\
\text { PER SCHOOL }\end{array}$ & 203 & 0 & 26.6 & 24.5 & 20.3 \\
\hline $\begin{array}{l}\text { PACT AREA } \\
\text { PUBIIC SCHOOL } \\
\text { AVERAGE }\end{array}$ & 505 & 29.0 & 33.0 & 29.0 & 19.0 \\
\hline $\begin{array}{l}\text { CITY OR } \\
\text { PORTLAND } \\
\text { SCHOOL } \\
\text { AVERAOE }\end{array}$ & 692 & 18.2 & 15.0 & 17.0 & 11.1 \\
\hline
\end{tabular}

sourCE: Individual Parish Census Statistics 
APPENDIX $C$

PACT Area School Statiatics 


\begin{tabular}{|l|c|c|c|c|}
\hline SCHOOL POPULATIONS AND SAMPLE DATA \\
\hline School & $\begin{array}{c}\text { Total } \\
\text { Enroll- } \\
\text { ment }\end{array}$ & $\begin{array}{c}\text { No. of } \\
\text { Class- } \\
\text { rooms }\end{array}$ & $\begin{array}{c}\text { No. of } \\
\text { Teachers } \\
\text { Sampled }\end{array}$ & $\begin{array}{c}\text { No. of Students } \\
\text { Identified as } \\
\text { Needful }\end{array}$ \\
\hline Abernethy & 466 & 20 & 4 & 48 \\
\hline Brooklyn & 352 & 14 & 2 & 23 \\
\hline Buckman & 525 & 21 & 4 & 42 \\
\hline Edwards & 310 & 11 & 2 & 13 \\
\hline Serms & 204 & 8 & 2 & 18 \\
\hline Richmond & 820 & 29 & 4 & 19 \\
\hline St. Prancis & 95 & 4 & 2 & 8 \\
\hline St. Philip Neri & 189 & 8 & 2 & 22 \\
\hline St. Stophen & 264 & 8 & 2 & 37 \\
\hline Sunnyside & 622 & 23 & 4 & 241 \\
\hline Trotals & 3847 & 146 & 28 & 21 \\
\hline
\end{tabular}

*Based on January 15, 1971, school enrollment figures. 
APPENDIX D

The Guided Interview Format 


\section{GUIDED INTERVIEW FORMAT}

\section{School:}

Teacher:

\section{Interview Date:}

1. How many students in your classroom?

2. Please estimate the number of students in your classroom who you feel would benefit from some form of mental health service (e.8. diagnosis, therapy, guidance, counseling, etc.) These youngsters may be seen as:
a. w1 thdrawn-anxious
b. immature-inadequate
o. aggressive-hostile

3. How many students have you referred for mental health services (1.e. diagnosis, therapy, suidance, counseling, etc.) during the current school year?

4. If there is a discrepancy between the responses given to \#2 and \#3 above, how would you explain the fact that only were referred for mental health services if children noedful. were seen as

5. Are you satisfled with the results obtained from referrals that have been made? Yes No - As an example, could you describe the process of the last referral you made: 
6. Do you feel it would be advantageous to have a children's mental health service agency located in the PACT* target area?

Yes

No

7. Ideally, what kind of oervices would such an agency provide in order to meet the needs which you see:

* Portiand Action Comittees Together, Inc. The OEO program whose geographical boundaries are shown on the attached census tract map. 